\title{
Pulmonary clearance of vasoactive intestinal peptide
}

\author{
MICHAEL P BARROWCLIFFE, ALYN MORICE, J GARETH JONES, \\ PETER S SEVER \\ From the Division of Anaesthesia, Clinical Research Centre, Harrow, and the Department of Clinical \\ Pharmacology and Therapeutics, St Mary's Hospital Medical School, London
}

ABSTRACT Vasoactive intestinal peptide causes bronchodilatation when given intravenously but is less effective in both animals and man when given by inhalation. This difference may be due to poor transit of the peptide across the bronchial epithelium. To test this hypothesis pulmonary clearance of radiolabelled vasoactive intestinal peptide was measured in Sprague Dawley rats and compared with that of pertechnetate $\left(\mathrm{TcO}_{4}{ }^{-}\right)$and diethylene triamine pentaacetate (DTPA). Despite a molecular weight (MW) of 3450, iodinated vasoactive intestinal peptide was cleared rapidly from the lungs, with a mean half time $(\mathrm{t} 1 / 2)$ of 19 minutes after an initial slower phase. This compares with a $t^{1 / 2}$ of 10 minutes with $\mathrm{TcO}_{4}^{-}$(MW 163) and a $t^{1} 1 / 2$ of 158 minutes with DTPA (MW 492). The possibility that vasoactive intestinal peptide mediates a non-specific increase in permeability was discounted by the fact that the combination of vasoactive intestinal peptide and DTPA did not alter DTPA clearance significantly. Chromatography and radioimmunoassay of blood taken after intratracheal administration of vasoactive intestinal peptide demonstrated a metabolite but no unchanged peptide. An intravenous injection of the peptide disappeared on first pass through the lung. It is concluded that inhaled vasoactive intestinal peptide lacks efficacy as a bronchodilator not because of slow diffusion to airway smooth muscle but because it is metabolised at an early stage of its passage through the respiratory epithelium.

Our understanding of the control of airways smooth muscle by the autonomic nervous system has advanced over the past decade with evidence of a third component, which may modulate smooth muscle activity - the non-adrenergic, non-cholinergic system. Electrical field stimulation of nerves investing airways smooth muscle produces an initial contraction, which is cholinergically mediated, followed by relaxation that is resistant to both cholinergic and adrenergic blockade. ${ }^{12} \mathrm{~A}$ major candidate for the role of neurotransmitter in this bronchodilator response is vasoactive intestinal peptide, a peptide of 28 amino acids. Nerves containing vasoactive intestinal peptide are present close to tracheal smooth muscle, bronchi, and major blood vessels in several species, including man, ${ }^{3}$ and vasoactive intestinal peptide relaxes airways smooth muscle in vitro via a non-adrenergic mechanism. ${ }^{4}$ In vivo it causes bronchodilatation when given intravenously both in $\operatorname{man}^{56}$ and in ani-

Address for reprint requests: Dr A Morice, Department of Clinical Pharmacology, St Mary's Hospital Medical School, London W2 1PG.

Accepted 17 September 1985 mals, ${ }^{7}$ but it is considerably less effective when administered via a nebuliser. ${ }^{7-10}$

Several explanations have been advanced for the apparent lack of efficacy of vasoactive intestinal peptide when given by inhalation. ${ }^{11}$ The peptide has a molecular weight of about 3300 daltons and possibly such a large molecule cannot cross the respiratory epithelium at a sufficient rate. Alternatively, vasoactive intestinal peptide may be inactivated during its passage through the bronchial epithelium.

In an attempt to resolve these questions we observed the fate of radiolabelled vasoactive intestinal peptide administered via the airways to rats, and compared the pulmonary handling of the peptide with that of two other radiolabelled compounds of differing molecular weight.

\section{Methods}

We used female Sprague Dawley rats, bred in a specific pathogen free unit and kept under standard animal husbandry conditions, with free access to water and a standard rodent diet. They weighed $200-300 \mathrm{~g}$ and were aged 6-12 weeks at the times of study. 
Animals were anaesthetised with halothane in oxygen, followed by $0.5 \mathrm{ml} / \mathrm{kg}$ Hyphorm (fentanyl 0.315 $\mathrm{mg} / \mathrm{ml}$ and fluanisone $10 \mathrm{mg} / \mathrm{ml}$, Crown Chemical Co, Lamberhurst, Kent) and atropine sulphate 0.6 $\mathrm{mg} / \mathrm{kg}$, both given by intraperitoneal injection. Endotracheal intubation was then performed under direct vision; we used as an endotracheal catheter an unmodified $16 \mathrm{G}$ Abbocath (Abbott Ireland Ltd, Sligo, Ireland), which is marketed for intravenous cannulation in humans. After intubation anaesthesia was maintained by halothane in oxygen given with intermittent positive pressure ventilation from a Harvard rodent respirator.

The following radiolabelled compounds were used: vasoactive intestinal peptide (VIP) labelled with iodine 125 (specific activity $2000 \mathrm{Ci} / \mathrm{mmol}$ and molecular weight (MW) 3450 daltons); pertechnetate $\left({ }^{99} \mathrm{TcO}_{4}{ }^{-}, \mathrm{MW} 163\right.$ daltons) obtained by elution from a molybdenum generator; and technetium labelled diethylenetriamine penta-acetate $\left({ }^{99 \mathrm{~m}} \mathrm{Tc}\right.$ DTPA, MW 492 daltons). All the compounds were from Amersham International, Amersham, Bucks.

Six groups of animals were studied. Group 1 contained six rats given ${ }^{99} \mathrm{TcO}_{4}{ }^{-}$, group 2 six rats given ${ }^{99 m}$ Tc DTPA, and group 3 six rats given ${ }^{125}$ I VIP. Peptidase inhibitors were given to two other groups: group 4 contained two rats given intravenous aprotinin (Bayer UK Ltd, Newbury, Berks) followed by intratracheal ${ }^{125} \mathrm{I}$ labelled vasoactive intestinal peptide ( ${ }^{125}$ I VIP), while group 5 comprised two rats given intravenous captopril (Squibb Pharmaceuticals, Princeton, New Jersey, USA) followed by intratracheal ${ }^{125}$ I VIP. Group 6 comprised six rats given ${ }^{99 \mathrm{~m}} \mathrm{Tc}$ DTPA as in group 2 , but this was mixed with unlabelled VIP, in the same molar quantity as the labelled VIP given to group 3.

Each radiolabelled compound was dissolved in isotonic saline, and instilled as a $0.1 \mathrm{ml}$ bolus into the animal's trachea by means of a fine catheter passed through the endotracheal catheter and sited just above the carina. Collimated scintillation detectors were positioned over the thorax and over one hind leg, and the number of counts per minute was recorded from each detector for up to 60 minutes. The chest detector registers activity from vascular tissue as well as lung tissue, and as the radiolabelled compound is transferred into the bloodstream vascular tissue contributes increasingly to the counts recorded. Jones et $a l^{12}$ have described a technique whereby the true rate of clearance from the lung can be determined. It requires the recording of counts over a remote field such as the leg, in which radioactivity changes in the same proportion as counts in the vascular tissue seen by the chest detector. At the end of the experiment therefore an intravenous injection of the radiolabelled compound was made, and the ratio of the increase in counts in the chest detector and the leg detector was determined. This ratio provided a correction factor, which was subtracted from the chest counts for each minute of recording. The remaining values represent the amount of radiolabelled compound remaining within the lung.

To identify vasoactive intestinal peptide or its metabolites in the bloodstream after intratracheal administration of ${ }^{125} \mathrm{I}$ VIP, $4 \mathrm{ml}$ blood was obtained from each of two rats 40 minutes after they had received intratracheal ${ }^{125}$ I VIP. Blood was centrifuged immediately and plasma frozen and stored at $-20^{\circ} \mathrm{C}$. An ethanolic extract of plasma was subjected to standard thin layer chromatography for amino acids ${ }^{13}$ on cellulose acetate paper with a solvent consisting of butanol $35 \%$, acetone $35 \%$, water $20 \%$, and glacial acetic acid $10 \%$.

Four further rats were given intratracheal unlabelled vasoactive intestinal peptide, and venous and arterial blood was taken for radioimmunoassay 20-40 minutes later.

\section{STATISTICAL ANALYSIS}

Analysis of variance was performed on log transformed data from the five groups. Dunnet's modification ${ }^{14}$ of Students $t$ test was then applied to compare group 3 with groups 1, 2, 4, and 5. Groups 2 and 6 were compared by Student's $t$ test.

\section{Results}

The measured water:toluene partition coefficient of vasoactive intestinal peptide was 0.0106 , confirming that the peptide is appreciably hydrophilic.

Plots of radioactivity versus time for representative animals given each radiolabelled compound are shown in figures 1-3. An index of pulmonary epithelial permeability was derived from the slope of the linear portion of each curve describing the fall in corrected lung activity, and expressed as the half time in minutes for transfer from lung to blood. These values are summarised in the table.

There was a significant difference $(p<0.01)$ between groups 3 and 1 and between groups 3 and 2, but no significant difference between groups 2 and 6 $(p=0.17)$.

Chromatographic analysis of blood from rats re-1 ceiving intratracheal ${ }^{125}$ I VIP only showed that the major component of plasma radioactivity did not rise with either iodotyrosine or ${ }^{125}$ I VIP.

Radioimmunoassay ${ }^{15}$ of blood from rats receiving intratracheal unlabelled VIP confirmed that there was no significant amount of unchanged VIP 20-40 minutes lảter. 


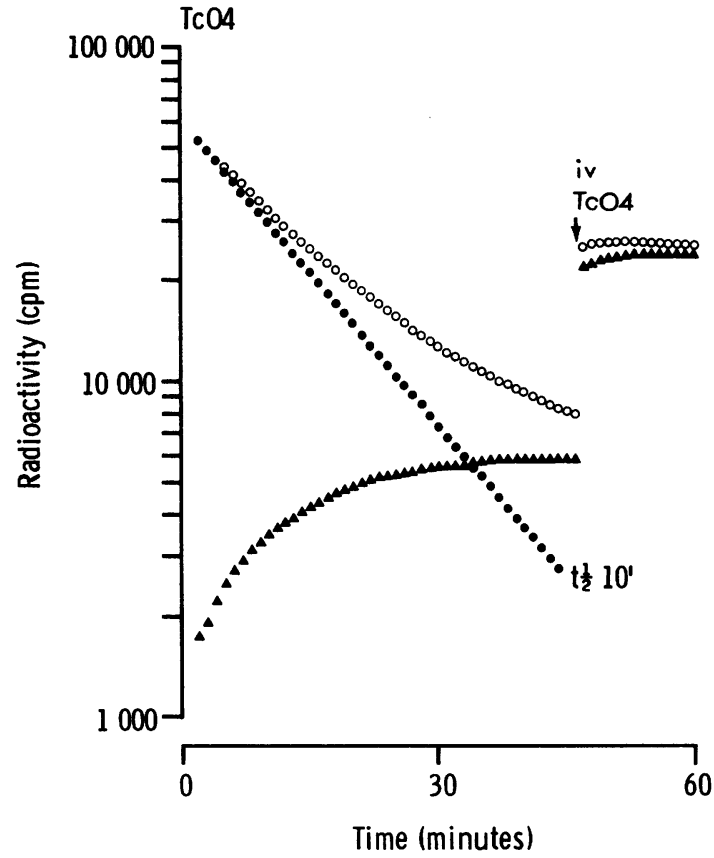

Fig 1 Plot of radioactivity versus time for a typical animal in group 1 given intratracheal pertechnetate $\left(\mathrm{TcO}_{4}^{-}\right)$and a subsequent intravenous injection of the same compound. Arrow indicates time of injection. $\Delta$ leg radioactivity; $\bigcirc$ recorded chest radioactivity, $\mathrm{C}$ corrected lung radioactivity.

\section{Discussion}

In vitro studies have suggested that vasoactive intestinal peptide should be a potent bronchodilator ${ }^{416}$ but in vivo it has surprisingly little effect on airway tone when inhaled as an aerosol. ${ }^{810}$ It confers limited protection against bronchoconstriction induced by histamine and prostaglandin $F_{2 \alpha}$ in the dog, ${ }^{17}$ and by histamine in guinea pigs ${ }^{18}$ and human asthmatic subjects. ${ }^{9}$ In cats, Diamond et al $^{7}$ observed that intravenous vasoactive intestinal peptide afforded appreciable protection against 5-hydroxytryptamine challenge but that only one out of six cats was protected when it was administered by aerosol. We have previously reported lack of bronchodilatation in human asthmatic subjects after nebulised vasoactive intestinal peptide in doses of up to $200 \mu \mathrm{g},{ }^{11}$ whereas intravenous administration caused significant bronchodilatation and appreciable protection against challenge with nebulised histamine. ${ }^{5}$

One possible explanation for the lack of effect of inhaled vasoactive intestinal peptide is that its permeability through the respiratory epithelium to its recep- tor site is restricted. We believe that the results of this experiment preclude this hypothesis, at least in the rat.

In this experiment the solutes DTPA and $\mathrm{T}_{c} \mathrm{O}_{4}{ }^{-}$ have been used to provide an index of the permeability of the respiratory epithelium and vascular endothelium. It is difficult to determine the exact site of absorption of these compounds. A bolus delivered to the trachea is obviously in contact with a considerable surface area of conducting airways before it reaches alveoli.

Vasoactive intestinal peptide is known to be a pulmonary vasodilator ${ }^{19}$ and its effects on pulmonary blood volume and flow might have an effect on our measured clearance rates. Since, however, the respiratory endothelium is a more substantial barrier than the vascular endothelium, ${ }^{20}$ any effect of the latter on clearance of the peptide is likely to be very slight.

Effros and Mason ${ }^{21}$ have summarised the relationship between solute clearance and molecular size in the lungs of various animals using a variety of experimental techniques, and figure 4 is adapted from their review. It would be expected that vasoactive intestinal peptide, a lipid insoluble molecule with a molecular weight over 3000 daltons, would have a prolonged half time, perhaps of the order of several hundred minutes. In the rat this was not the case, the mean half time being 19 minutes.

The rate of decline of radiolabelled vasoactive intestinal peptide is initially slow (fig 3), and possibly this represents an initial phase of passive diffusion, limited by molecular size. The subsequent rapid rate of decline of radioactivity could be due to several mechanisms. The presence and passage of a small part of the tracheally instilled vasoactive intestinal peptide might subsequently increase the permeability of the respiratory epithelium to the peptide remaining within the airways and alveoli. If so, a molecule such as DTPA mixed with vasoactive intestinal peptide should behave in a similar fashion to the peptide, and show increased pulmonary clearance, at least as fast as that of the peptide. We tested this hypothesis by comparing group 2 (given ${ }^{99 m}$ Tc DTPA alone) with group 6 (given ${ }^{99 \mathrm{~m}}$ Tc DTPA plus unlabelled VIP) and found no difference in the overall shapes of the clearance curves. The mean half time for group 6 was lower but the difference was not significant, so it seems unlikely that vasoactive intestinal peptide is able to mediate an appreciable increase in epithelial permeability.

The surprisingly rapid pulmonary clearance of vasoactive intestinal peptide might be accounted for by active transport of the unchanged compound. Chromatography and radioimmunoassay, however, indicated that there was no detectable unchanged peptide in venous or arterial blood, but that the radio- 


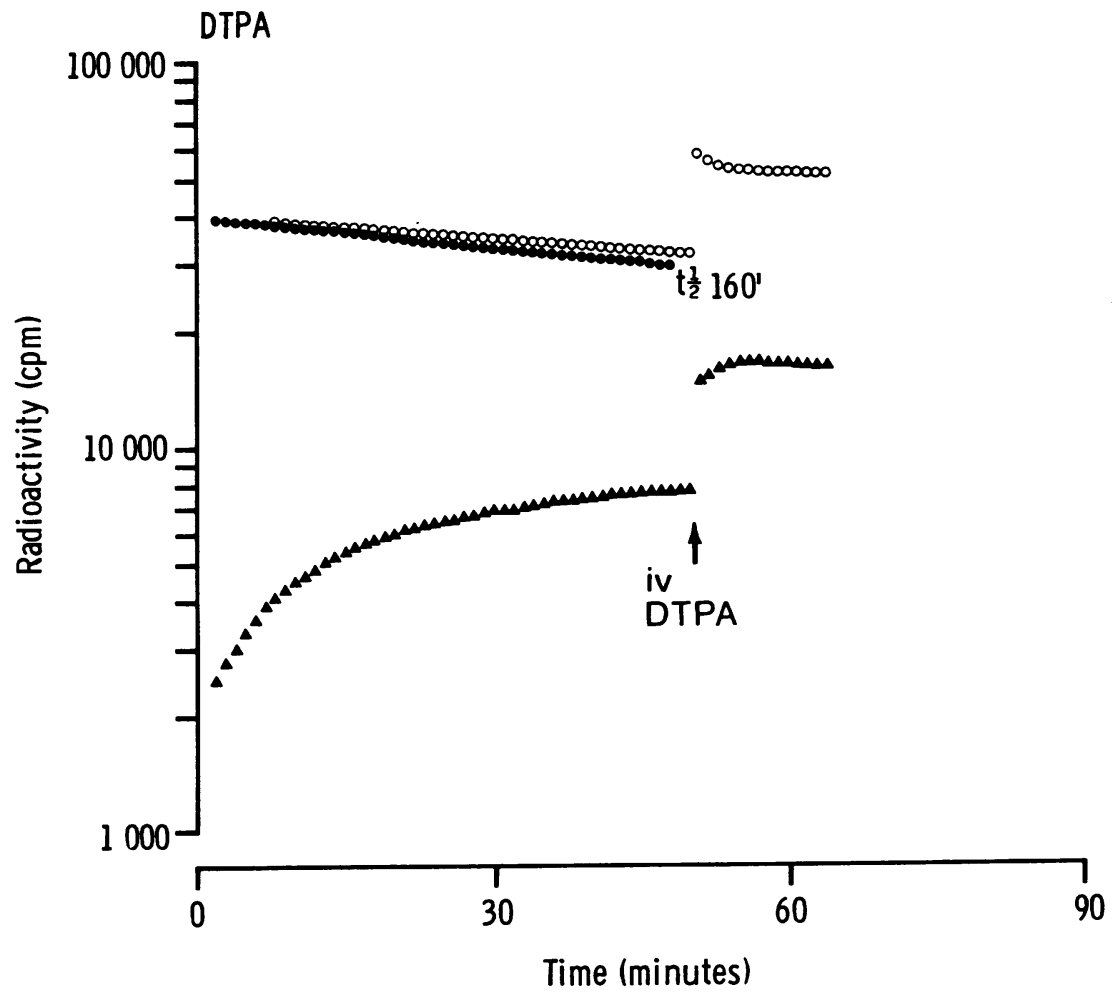

Fig 2 Plot of radioactivity versus time for a typical animal in group 2 given intratracheal ${ }^{99 \mathrm{~m}} \mathrm{Tc}$ labelled diethylene triamine penta-acetate (DTPA) and $a$ subsequent intravenous injection of the same compound. Arrow indicates time of injection. $\Delta$ leg radioactivity; O recorded chest radioactivity, corrected lung radioactivity.

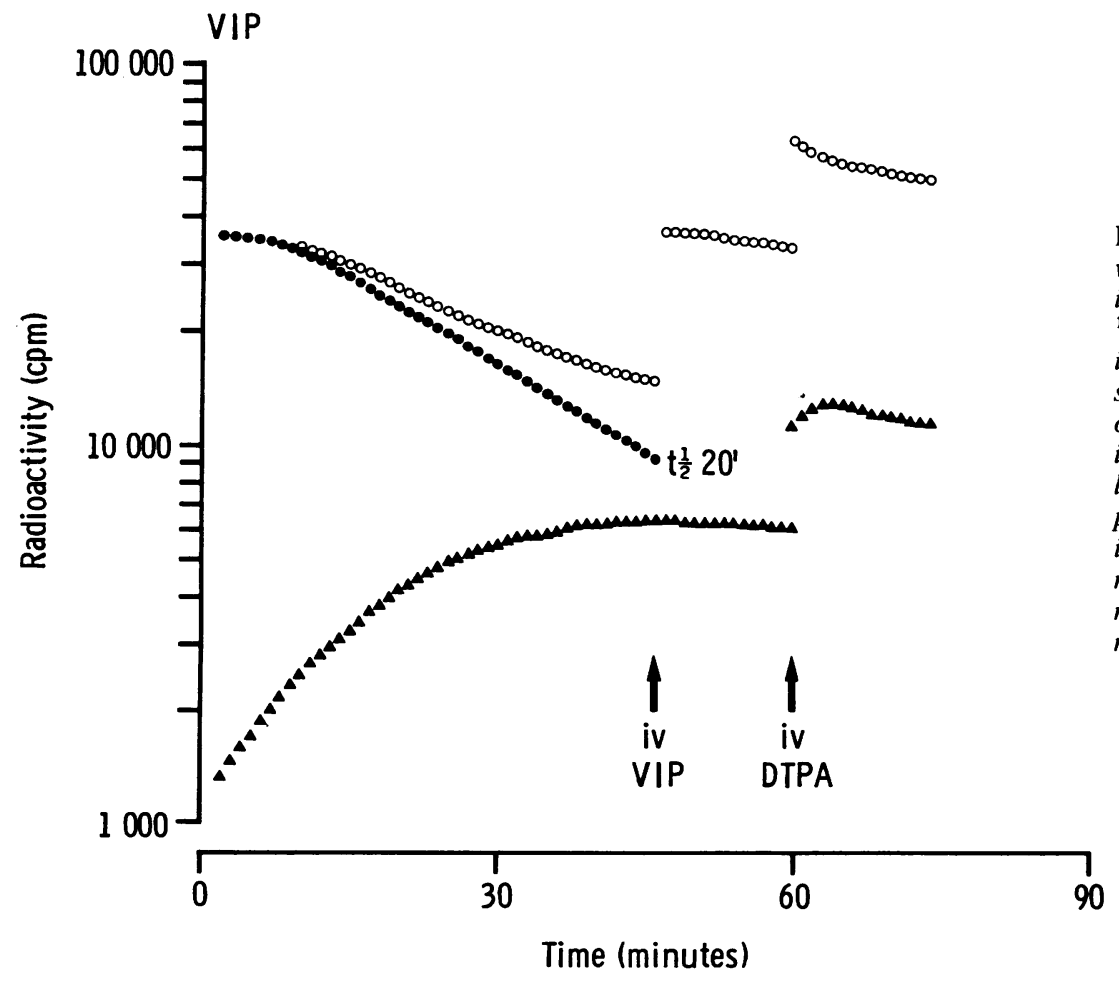

Fig 3 Plot of radioactivity versus time for a typical animal in group 3 given intratracheal ${ }^{125}$ I labelled vasoactive intestinal peptide (VIP) and a subsequent intravenous injection of ${ }^{125}$ IVIP, followed by an intravenous injection of ${ }^{99 \mathrm{~m}} \mathrm{Tc}$ labelled diethylene triamine penta-acetate (DTPA). Arrows indicate time of injections. $\Delta$ leg radioactivity; $\bigcirc$ recorded chest radioactivity, corrected lung radioactivity. 
Half time $(T 1 / 2)$ in minutes for transfer of radioactivity from lung to blood in the six groups

\begin{tabular}{llc}
\hline Group & No of animals & $\begin{array}{l}\text { T1/2 } \\
(\text { mean }(S D))\end{array}$ \\
\hline 1: Pertechnetate & 6 & $10(1.3)$ \\
2: $99 \mathrm{~m}$ Tc DTPA & 6 & $158(12)$ \\
3: 125 I VIP & 6 & $19(2)$ \\
4: 125 I VIP, aprotinin & 2 & 20.5 \\
5: 125 I VIP, captopril & 2 & 21.5 \\
6: 99 Tc DTPA, VIP & 6 & $107(40)$ \\
\hline
\end{tabular}
${ }^{99 m}$ Tc DTPA-technetium ${ }^{99 m}$ labelled diethylene triaminepenta-
acetate; ${ }^{125} \mathrm{I}$ VIP-iodine ${ }^{125}$ labelled vasoactive intestinal peptide.

active label was attached to some metabolite of vasoactive intestinal peptide. These results suggest that VIP is metabolised at the epithelial surface and that the labelled metabolite is transferred by rapid diffusion or active transport into the blood. There remains the possibility, however, that vasoactive intestinal peptide is transported unchanged across the epithelium, but is subsequently rapidly metabolised so that no unchanged peptide gains access to or remains within the circulation. This latter notion gains credence from our finding that intravenous ${ }^{125}$ I VIP (administered via a tail vein) consistently resulted in a rise in chest counts, but no increase in counts from the leg (fig 3). A subsequent intravenous injection of ${ }^{99 \mathrm{~m}}$ Tc DTPA was made in this group of animals (to obtain the necessary factor for calculating corrected lung activity). The fact that all intravenously adminis-

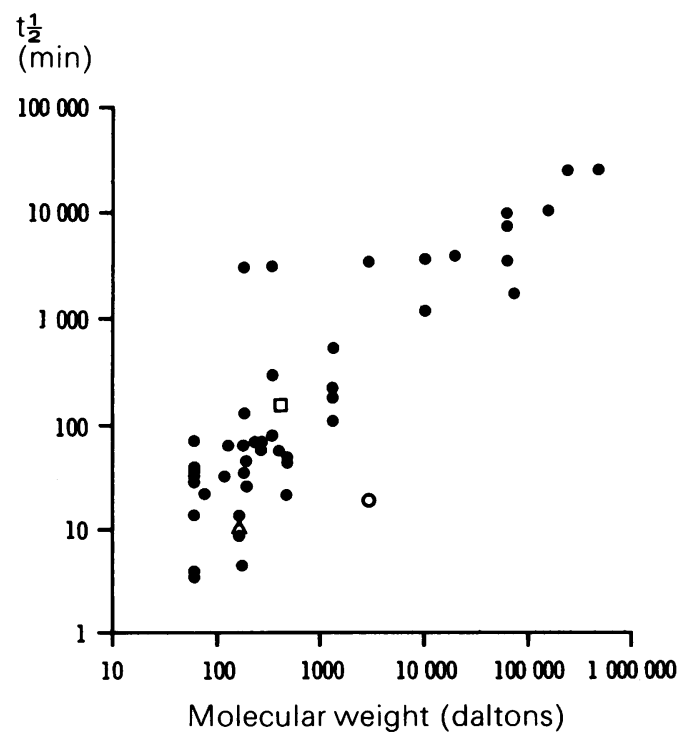

Fig 4 Relationship between solute clearance from the lungs and molecular weight. data reviewed by Effros and Mason ${ }^{18}$; open symbols represent data presented in this paper. tered ${ }^{125}$ I VIP was removed during a single pass through the lung suggests that the lung may be an important site of clearance of the peptide from the circulation in the rat. This appears to contrast with findings in anaesthetised dogs, ${ }^{22}$ where enhanced cardiovascular effects were observed after passage of the peptide through the lungs. Some of the effects observed after vasoactive intestinal peptide may be due to the secondary release or activation of vasoactive compounds.

In an attempt to inhibit metabolism of vasoactive intestinal peptide, we administered a serine protease inhibitor, aprotinin, and an angiotensin converting enzyme inhibitor, captopril. The dose of aprotinin was chosen empirically; that of captopril was sufficient to have an effect on the activity of angiotensin converting enzyme in the rat. ${ }^{23}$ Neither agent had any discernible effect on pulmonary handling of vasoactive intestinal peptide, and this accords with their failure to prolong the relaxation of smooth muscle induced by the peptide in vitro in the cat. ${ }^{19}$

If our findings in the rat can be applied to other animals, then the lack of bronchodilator effect of aerosolised vasoactive intestinal peptide is unlikely to be due to restricted passage of the molecule through the respiratory epithelium to its receptor site. Facilitated passage of the peptide followed by rapid metabolism, or metabolism preceding passage across the epithelium, is a more likely explanation.

\section{References}

1 Coburn RF, Tomita T. Evidence for nonadrenergic inhibitory nerves in the guinea pig trachealis muscle. $\mathrm{Am}$ J Physiol 1973;224:1072-80.

2 Richardson J, Beland J. Nonadrenergic inhibitory nervous system in human airways. $J$ Appl Physiol 1976;41:764-70.

3 Dey DA, Shannon WA, Said SI. Localization of V.I.P. immunoreactive nerves in airways and pulmonary vessels of dogs, cats and human subjects. Cell Tiss Res 1981;220:231-8.

4 Altiere RJ, Diamond L. Comparison of vasoactive intestinal peptide and isoproterenol relaxant effect in isolated cat airways. J Appl Physiol: Respirat Environ Exercise Physiol 1984;56:986-92.

5 Morice A, Unwin R, Sever PS. Vasoactive intestinal peptide causes bronchodilatation and protects against histamine induced bronchoconstriction in asthmatic subjects. Lancet 1983;ii:1225-7.

6 Morice A, Sever PS. The use of vasoactive intestinal peptide in severe acute asthma. Thorax 1984;39:707.

7 Diamond L, Szarek JL, Gillespie MN, Altiere RJ. In vivo bronchodilator activity of vasoactive intestinal peptide in the cat. Am Rev Respir Dis 1983;128:827-32.

8 Bundgaard A, Enehjelm SD, Aggestrup S. Pretreatment of exercise-induced asthma with inhaled va- 
soactive intestinal peptide (VIP). Eur $J$ Respir Dis 1983;64, suppl 128:427-9.

9 Barnes PJ, Dixon CMS. The effect of inhaled vasoactive intestinal peptide on bronchial reactivity to histamine in humans. Am Rev Respir Dis 1984;130:162-6.

10 Altiere RJ, Kung M, Diamond L. Comparative effects of inhaled isoproterenol and vasoactive intestinal peptide on histamine-induced bronchoconstriction in human subjects. Chest 1984;86:153-4.

11 Morice A, Unwin RJ, Sever PS. In vivo bronchodilating activity of vasoactive intestinal peptide in the cat. Am Rev Respir Dis 1984;129:882.

12 Jones JG, Minty BD, Lawler P, Hulands G, Crawley $\mathrm{JCW}$, Veall $\mathbf{N}$. Increased alveolar epithelial permeability in cigarette smokers. Lancet 1980;1:66-8.

13 Wooton IDP. Microanalysis in medical biochemistry. 6th ed. Edinburgh: Churchill Livingstone, 1982:193-9.

14 Gill JL. Design and Analysis of Experiments. Vol 1. Ames, Iowa: Iowa State University Press, 1978:183.

15 Dimaline R, Dockray GJ. Multiple immunoreactive forms of vasoactive intestinal peptide in human colonic mucosa. Gastroenterology 1978;75:387-92.

16 Wasserman MA, Griffin RL, Malo PE. Comparative in vivo tracheal relaxant effects of porcine and hen VIP. In: Said SI, ed. Vasoactive intestinal peptide. New York: Raven Press, 1982:177-84.
17 Said SI, Geumei A, Hara N. Bronchodilator effect of V.I.P. in vivo: protection against bronchoconstriction induced by histamine or prostaglandin $F_{2}$ alpha. In: Said SI, ed. Vasoactive intestinal peptide. New York: Raven Press, 1982:185-91.

18 Cox CP, Lerner MR, Wells JH, Said SI. Inhaled vasoactive intestinal peptide (VIP) prevents bronchoconstriction induced by inhaled histamine. Am Rev Respir Dis 1983;127:249.

19 Altiere RJ, Diamond L. Relaxation of cat tracheobronchial and pulmonary arterial smooth muscle by vasoactive intestinal peptide: lack of influence by peptidase inhibitors. $\mathrm{Br} J$ Pharmacol 1984;82:321-8.

20 Taylor AE, Gaar KA. Estimation of equivalent pore radius of pulmonary capillary and alveolar membranes. Am J Physiol 1970;218:1133-40.

21 Effros RM, Mason GR. Measurements of pulmonary epithelial permeability in vivo. Am Rev Respir Dis 1983;127:S59-65.

22 Kitamura S, Yoshida T, Said S. Vasoactive intestinal polypeptide: inactivation in liver and potentiation in lung of anaesthetised dogs. Proc Soc Exp Biol Med 1975;148:25-9.

23 Johnston CI, Millar JA, Casley DJ, McGrath BP, Matthews PG. Hormonal responses to angiotensin blockade. Circul Res 1980;46 suppl I:128-34. 